\title{
POLICE AND JUDICIAL COOPERATION IN CRIMINAL MATTERS IN THE EUROPEAN UNION
}

\author{
Avrupa Birliği’nde Cezai Konularda Polis ve Adli İsbirliği
}

Güneş OKUYUCU ERGÜN*

\begin{abstract}
Cooperation in criminal matters in the EU is probably one of the most delicate issues in the area of harmonisation as it deals with two very sensitive matters, namely, the sovereignty of Member States and the protection of human rights. Despite such delicacy, the police and judicial cooperation in criminal matters has been one of the fastest-growing areas of the EU law especially after the Treaty of Lisbon where certain competences in criminal matters were conferred to the EU. This paper concentrates on the main areas for police and judicial cooperation and the types of available legal instruments. This paper suggests that increasing the cooperation in an effective and sustainable manner would require a balanced approach between the security and the protection of fundamental rights.
\end{abstract}

Key Words: Judicial cooperation in criminal matters, police cooperation, European arrest warrant, mutual recognition, European Union criminal law.

\section{$\ddot{\mathbf{O z}}$}

Cezai konularda işbirliği, Üye Ülkelerin egemenlikleri ve insan haklarının korunması gibi iki oldukça duyarlı konuya temas etmesi dolayısıyla muhtemelen AB'nin uyumlaştırma alanındaki en hassas meselelerinden biridir. $\mathrm{Bu}$ hassas yönüne karşın, cezai konularda polis ve adli işbirliği, özellikle cezai konularda bazı yetkilerin AB'ye devredildiği Lizbon Antlaşmasından sonra $\mathrm{AB}$ hukukunun en hızlı gelişen alanlarından biri

* Makalenin Geliş Tarihi: 19.03.2021, Makalenin Kabul Tarihi: 23.04.2021.

Assoc. Prof., University of Ankara, Criminal Law and Criminal Procedural Law Department of the Faculty of Law. (okuyucu@law.ankara.edu.tr, ORCID: https://orcid.org/0000-00015401-2312). 
olmuştur. Bu çalışmada, polis ve adli işbirliğine konu başlıca alanlar ve işbirliğinde kullanılan hukuki enstrümanlar ele alınmakta ve işbirliğinin etkili ve sürdürülebilir bir şekilde artırılması için güvenlik ve bireylerin temel haklarının korunması arasında dengeli bir yaklaşımın benimsenmesinin gerekliliği vurgulanmaktadır.

Anahtar Kelimeler: Cezai konularda adli işbirliği, polis işbirliği, Avrupa tutuklama müzekkeresi, karşılıklı tanıma, Avrupa Birliği ceza hukuku.

\section{INTRODUCTION}

Freedom of movement and the increasing mobility of people across Europe was the main motive for the EU law makers and enforcement authorities to strengthen the police and judicial cooperation ever since the Amsterdam Treaty. However, the rapid expansion of internet has provided new opportunities for cross-border crimes and necessitated a more urgent international response to combat such crimes more than ever. Since early 2000 s, the adoption of EU-wide and other international measures against cyber-crimes has been among the priorities of the EU police and judicial cooperation agencies and the United Nations.

The September 11 attacks in the United States and the recent intensification of the refugee problem in the EU also led to a more pressing necessity to move the focus from the national sphere to a widest international context, and to adopt new ways of judicial cooperation protecting the supranational interest.

Moreover, the globalisation and the increasing complexity of the financial markets and instruments over the past few decades have also posed a specific challenge to judicial cooperation in the EU, as the effects of financial crimes are, in many cases, cross-national.

In this paper, we will review and analyse the police and judicial cooperation in criminal matters in the EU from the perspective of both cooperation areas and the instruments used in such cooperation. The topic merits a basic reconsideration by reason of contemporary developments that put in question the pressing need for international cooperation in police and judicial cooperation, on one hand, and the protection of human rights and fundamental freedoms, on the other. The study concentrates on two central themes. First part focuses on the main areas for cooperation while the second part analyses various types of legal instruments used for cooperation in such areas. In the conclusion part, we shall draw together a number of aspects resulting from the analysis made in this paper with concluding remarks on the 
need for a balanced approach between the cooperation in criminal matters and the protection of fundamental rights and freedoms.

\section{MAIN AREAS FOR COOPERATION}

The police and judicial cooperation in criminal matters aim to tackle the challenge of cross-border serious crimes across the EU. Article 83 of the Treaty on the Functioning of the European Union (TFEU), which is the main legal basis of the police and judicial cooperation in criminal matters in the EU, empowers the European Parliament and the Council to establish minimum rules concerning the definition of criminal offences and sanctions in the areas of particularly serious crime with a cross-border dimension. Such areas for cooperation include fight against, among other crimes, terrorism, illicit drug trafficking, money laundering, corruption, counterfeiting of means of payment, and cybercrimes.

\section{A. Fight against Terrorism}

Fight against terrorism is a top priority for the EU, as it raises an important security concern across the Union. According to Europol's EU Terrorism Situation and Trend Report 2020, in 2019, a total of 119 foiled, failed and completed terrorist attacks were reported, 1.004 individuals were arrested on suspicion of terrorism-related offences, and ten people died because of terrorist attacks in the EU and 27 people were injured. ${ }^{1}$

Following a series of terrorist attacks in the EU in $2015^{2}$, the EU has adopted some legislative measures to fight against terrorism. In April 2016, the Directive (EU) 2016/681 of the European Parliament and of the Council on the use of passenger name record (PNR) data for the prevention, detection, investigation and prosecution of terrorist offences and serious crime was adopted. ${ }^{3}$ The Directive provides for the transfer by air carriers of PNR data of passengers of extra-EU flights, and the processing of such data, including its collection, use and retention by Member States and its exchange

1 “EU Terrorism Situation and Trend Report 2020,” Europol, accessed January 10, 2021, https://www.europol.europa.eu/sites/default/files/documents/european_union_terrorism_ situation_and_trend_report_te-sat_2020_0.pdf.

2 "211 Terrorist Attacks Carried out in the Member States in 2015," Europol, accessed January 10, 2021, https://www.europol.europa.eu/ newsroom/news/211-terrorist-attackscarried-out-in-eu-member-states-in-2015-new-europol-report-reveals.

3 "Directive (EU) 2016/681 of the European Parliament and of the Council of 27 April 2016 on the Use of Passenger Name Record (PNR) Data for the Prevention, Detection, Investigation and Prosecution of Terrorist Offences and Serious Crime," accessed January 10, 2021, https://eur-lex.europa.eu/eli/dir/2016/681/oj. 
between Member States. The Directive clarifies that such data may be processed only for the purposes of preventing, detecting, investigating and prosecuting terrorist offences and serious crime (Article 1).

The Directive 2016/681 contains certain important safeguards to protect the fundamental rights, such as Article 13, which provides that every passenger has the same right to protection of their personal data, rights of access, rectification, erasure and restriction and rights to compensation and judicial redress as laid down in the EU and national laws. Furthermore, any assessment of passengers prior to their scheduled arrival in or departure from the Member State must be carried out in a non-discriminatory manner. Those pre-determined criteria must in no circumstances be based on a person's race or ethnic origin, political opinions, religion or philosophical beliefs, trade union membership, health, sexual life or sexual orientation. (Article 6.4). Moreover, the transfer of PNR data may only be made on a case-by-case basis and, in the event of automated processing of PNR data, after individual review by non-automated means (Article 6.6).

However, despite such positive aspects of the Directive 2016/681 with respect to the protection of fundamental rights, it has still some important shortcomings in that area. For instance, in order to detect and persecuting persons potentially involved in criminal or terroristic affairs, the Directive allows the systematic, blanket and indiscriminate transfer, storage and processing of a wide range of personal data of millions of travellers from and to the EU, and such a prior and general assessment of all passengers on the basis of predetermined criteria may clearly affect fundamental rights. ${ }^{4}$

In 2017, a new and more general legislative measure against terrorism, namely the Directive (EU) 2017/541 on combating terrorism ${ }^{5}$, was adopted. The Directive establishes minimum rules concerning the definition of criminal offences and sanctions in the area of terrorist offences, offences related to a terrorist group and offences related to terrorist activities, as well as measures of protection of, and support and assistance to, victims of terrorism (Article $1)$.

4 Susanna Villani, "Some Further Reflections on the Directive (EU) 2016/681 on PNR Data in the Light of the CJEU Opinion 1/15 of 26 July 2017," Revista de Derecho Politico 1 (April 28, 2018): 916.

5 "Directive (EU) 2017/541 of the European Parliament and of the Council of 15 March 2017 on Combating Terrorism and Replacing Council Framework Decision 2002/475/JHA and Amending Council Decision 2005/671/JHA,” Pub. L. No. 32017L0541, 088088 (2017), http://data.europa.eu/eli/dir/2017/541/oj/eng. 
Recently, in November 2020, following the terrorist attacks in France, Germany and Austria, a joint statement was published by the EU home affairs ministers to strengthen their joint efforts to fight terrorism. ${ }^{6}$ The Joint Statement also reaffirms that such efforts against terrorism will in no way compromise on EU's shared belief in human dignity, tolerance, democracy, justice and freedom, including freedom of speech. In December 2020, EU leaders also reaffirmed their unity in the fight against terrorism in the European Council Conclusions. ${ }^{7}$

Policy makers and law enforcement authorities should strike a delicate balance between fight against terrorism and the protection of human rights. While terrorism itself constitutes a serious threat to human rights, and therefore strict measures are needed, they should not be taken at the cost of jeopardizing the core of human rights. The provisions of the relevant legislative acts and the statements of the leaders, including the Joint Statement of November 2020, which are aimed to protect the human rights while fighting against terrorism are positive developments, it still remains to be seen to what extent such balance will be achieved in pratice.

\section{B. Fight against Drug Trafficking}

The drug trafficking is a matter of significant concern for the EU as well as the entire international community, and a major source of income for organised crime groups in the EU. The illicit drug market in the EU is estimated at a minimum retail value of EUR 30 billion per year. ${ }^{8}$

Drug trafficking is one of the most important and oldest area of police and judicial cooperation in the EU. The European Monitoring Centre for Drugs and Drug Addiction (EMCDDA) was established in 1993 to provide the EU and the Member States with a factual overview of European drug problems and a solid evidence base to support the drugs debate. ${ }^{9}$

Drug trafficking is among the types of crime that are covered by both the European Police Office (Europol), the European Union Agency for Criminal

6 "Joint Statement by the EU Home Affairs Ministers on the Recent Terrorist Attacks in Europe," accessed January 10, 2021, https://www.consilium.europa.eu/en/press/pressreleases/2020/11/13/joint-statement-by-the-eu-home-affairs-ministers-on-the-recentterrorist-attacks-in-europe/.

7 "European Council Conclusions, 10-11 December 2020," n.d., https://www.consilium.europa.eu/media/47296/1011-12-20-euco-conclusions-en.pdf.

8 European Monitoring Centre for Drugs and Drug Addiction. and European Union Agency for Law Enforcement Cooperation., EU Drug Markets Report 2019. (LU: Publications Office, 2019), 13, https://data.europa.eu/doi/10.2810/561192.

9 See "EMCDDA I About," accessed January 10, 2021, https://www.emcdda.europa.eu/about. 
Justice Cooperation (Eurojust) and the European Public Prosecutor's Office (EPPO). It is specifically referred to in several of the legislative acts regarding the police and judicial cooperation in the EU, including the Convention on extradition between member states of European Union ${ }^{10}$, the Directive (EU) 2017/2103 amending Council Framework Decision 2004/757/JHA in order to include new psychoactive substances in the definition of "drug"" , and the Regulation (EC) No 1920/2006 on the European Monitoring Centre for Drugs and Drug Addiction. ${ }^{12}$

During the COVID-19 pandemic, despite the restrictions of movement, the movement of bulk quantities of drugs between Member States remained largely unaffected and the organised crime groups remained active and resilient, by adapting transportation models, trafficking routes and concealment methods. ${ }^{13}$ On 24 July 2020, the European Commission adopted a new EU Agenda and Action Plan on Drugs 2021-2025 as part of the Security Union Strategy. The new EU Agenda and Action Plan sets out the political framework and priorities with the aim of protecting citizens through better coordinated measures that will have a substantive and measurable impact on the security and health issues arising from drug use and the operations of the drug market; and address both the direct and indirect consequences arising from this problem. ${ }^{14}$

\section{Fight against Corruption, Fraud and Money Laundering}

Fight against financial crimes is among the priority objectives of the EU institutions as they pose serious threats to the security and the financial interests of the EU. Therefore, certain agencies have been formed to

10 Signed on 27 September 1996. Official Journal C 313, 23 October 1996, p.11.

11 "Directive (EU) 2017/2103 of the European Parliament and of the Council of 15 November 2017 Amending Council Framework Decision 2004/757/JHA in Order to Include New Psychoactive Substances in the Definition of 'Drug' and Repealing Council Decision 2005/387/JHA,” Pub. L. No. 32017L2103, $305305 \quad$ (2017), 12-18, http://data.europa.eu/eli/dir/2017/2103/oj/eng.

12 "Regulation (EC) No 1920/2006 of the European Parliament and of the Council of 12 December 2006 on the European Monitoring Centre for Drugs and Drug Addiction (Recast)," Pub. L. No. 32006R1920, 376 OJ L (2006), 1-13, http://data.europa.eu/eli/reg/2006/1920/oj/eng.

13 European Monitoring Centre for Drugs and Drug Addiction. and European Police Office., EU Drug Markets: Impact of COVID 19. (LU: Publications Office, 2020), https://data.europa.eu/doi/10.2810/19284.

14 "EU Agenda and Action Plan on Drugs 2021-2025," European Economic and Social Committee, September 19, 2020, https://www.eesc.europa.eu/en/our-work/opinionsinformation-reports/opinions/eu-agenda-and-action-plan-drugs-2021-2025. 
strengthen and coordinate the efforts against financial crimes, such as the European Anti-Fraud Office (OLAF), which conducts independent administrative investigations into fraud, corruption and any other illegal activity involving EU funds or revenue, and the EPPO, which is authorised to conduct criminal investigations and to prosecute fraud and corruption affecting the EU's financial interests.

The legal basis for combating financial crimes is Article 325 of the Treaty on the Functioning of the European Union (TFEU), which requires the Union and the Member States to counter fraud and any other illegal activities affecting the financial interests of the Union. In addition, Article 83 of the TFEU lists certain financial crimes, such as money laundering, corruption, counterfeiting of means of payment, among the particularly serious crimes with a cross-border dimension.

Fraud is one of the most important types of financial crimes. Until recently, the Convention on the protection of the European Communities' financial interests of 26 July $1995^{15}$ (also known as the Europol Convention), which was drawn up on the basis of Article K.3 (2) (c) of the Treaty on European Union, and the Protocols thereto of 27 September $1996^{16}$, of 29 November $1996^{17}$ and of 19 June $1997^{18}$, established the minimum rules relating to the fraud affecting the Union's financial interests. In 2017, the Directive (EU) 2017/1371 on the fight against fraud to the Union's financial interests by means of criminal law ${ }^{19}$ was adopted to replace the Convention. The Directive 2017/1371 entered into force on 6 July 2019.

15 "Council Act of 26 July 1995 Drawing up the Convention on the Protection of the European Communities' Financial Interests," 48, accessed January 10, 2021, https://eurlex.europa.eu/legal-content/EN/TXT/?uri=CELEX\%3A31995F1127\%2803\%29.

16 "Official Journal of the European Communities, C 313, 23 October 1996," 1, accessed January $\quad 10, \quad 2021, \quad$ https://eur-lex.europa.eu/legalcontent/en/ALL/?uri=OJ\%3AC\%3A1996\%3A313\%3ATOC.

17 "Official Journal of the European Communities, C 151, 20 May 1997," 1, accessed January 10, 2021, https://eur-lex.europa.eu/legalcontent/en/ALL/?uri=OJ\%3AC\%3A1997\%3A151\%3ATOC.

18 "Council Act of 19 June 1997 Drawing up, on the Basis of Article K.3 of the Treaty on European Union and Article 41 (3) of the Europol Convention, the Protocol on the Privileges and Immunities of Europol, the Members of Its Organs, the Deputy Directors and Employees of Europol," 11, accessed January 10, 2021, https://eur-lex.europa.eu/legalcontent/EN/TXT/?uri=CELEX\%3A31997F0719\%2801\%29\&qid=1610297224330.

19 "Official Journal of the European Union, L 198, 28 July 2017," 29-41, accessed January 10 , 2021, https://eur-lex.europa.eu/legalcontent/EN/TXT/?uri=OJ\%3AL\%3A2017\%3A198\%3ATOC. 
Pursuant to the Directive 2017/1371, in all Member States (except Denmark) these offences as well as their attempt, incitement, aiding and abetting, are to be punished as criminal offences (Article 5.1). The Directive provides that the Member States must ensure that the relevant criminal offences are punishable by "effective, proportionate and dissuasive" criminal sanctions (Article 7.1). Member States may also provide for a maximum sanction of at least four years of imprisonment in other serious circumstances defined in their national law (Article 7.3). As for the legal entities, the Directive envisages various other types of sanctions in addition to fines (criminal and non-criminal), such as the exclusion from entitlement to public benefits or aid; temporary or permanent exclusion from public tender procedures; temporary or permanent disqualification from the practice of commercial activities; placing under judicial supervision; judicial windingup; and temporary or permanent closure of establishments which have been used for committing the criminal offence (Article 9). The Directive also envisages the freezing and confiscation of means and proceeds from the criminal offences that affect the EU budget (Article 10); establishing jurisdiction for such offences (Article 11); minimum limitation periods for initiating investigations and prosecutions (Article 12).

Another aspect of the fight against financial crimes is to prevent the market abuse. The smooth functioning of securities markets and public confidence in markets are prerequisites for economic growth and wealth, and market abuse harms the integrity of financial markets and public confidence in securities, derivatives and benchmarks. ${ }^{20}$ To fight against market abuse, the Directive 2014/57/EU on criminal sanctions for market abuse ${ }^{21}$ was adopted in 2014.

The Market Abuse Directive envisages for sanctions for both individuals and legal entities that are involved in such crimes. For individuals, insider dealing and market manipulation, two major forms of market abuse, are punishable by a maximum term of imprisonment of at least 4 years (Article 7). For legal entities, criminal or non-criminal fines may be imposed and other sanctions may be applied, such as, (a) exclusion from entitlement to public benefits or aid; (b) temporary or permanent disqualification from the practice

20 "Directive 2014/57/EU of the European Parliament and of the Council of 16 April 2014 on Criminal Sanctions for Market Abuse (Market Abuse Directive)," Pub. L. No. 32014L0057, 173173 (2014), http://data.europa.eu/eli/dir/2014/57/oj/eng.

21 "Official Journal of the European Union, L 173, 12 June 2014," 179-89, accessed January 10, 2021, https://eur-lex.europa.eu/legal-content/EN/TXT/?uri=OJ\%3AL\%3A2014\% 3 A $173 \% 3$ ATOC. 
of commercial activities; (c) placing under judicial supervision; (d) judicial winding-up; (e) temporary or permanent closure of establishments which have been used for committing the offence (Article 9).

The Regulation (EU) No 596/2014 further strengthens administrative sanctions that can be imposed for market abuses and the national regulators' investigative powers to detect such crimes. ${ }^{22}$

Protection of the Euro and other currencies against counterfeiting is another aspect of the fight against financial crimes. According to a report prepared by the EU Intellectual Property Office (EUIPO), the Member States lose $€ 15$ billion of tax revenues and more than 670,000 legitimate jobs are lost because of counterfeiting annually. ${ }^{23}$

To tackle counterfeiting, the European Parliament and of the Council adopted the Directive 2014/62/EU on the protection of the euro and other currencies against counterfeiting by criminal law. ${ }^{24}$ The Directive provides that the Member States shall take the necessary measures to ensure that the following conduct is punishable as a criminal offence, when committed intentionally: (a) any fraudulent making or altering of currency; (b) the fraudulent uttering of counterfeit currency; (c) the import, export, transport, receiving or obtaining of counterfeit currency with a view to uttering the same and with knowledge that it is counterfeit; (d) the fraudulent making, receiving, obtaining or possession of any means peculiarly adapted for the counterfeiting or altering of currency, or security features which serve to protect against counterfeiting (Article 3). In 2019, the European Parliament and of the Council adopted the Directive (EU) $2019 / 713^{25}$ to regulate the measures against the counterfeiting of non-cash means of payment. The Directive defines "non-cash payment instrument" as a non-corporeal or corporeal protected device, object or record, or a combination thereof, other than legal tender, and which, alone or in conjunction with a procedure or a set of

22 Ibid., 1-61.

23 See Euronews, "EU Countries Lose $€ 15$ Billion in Tax Revenues to Counterfeiting, Says New Report," accessed January 10, 2021, https://www.euronews.com/2020/06/10/eucountries-lose-15-billion-in-tax-revenues-to-counterfeiting-says-new-report.

24 "Directive 2014/62/EU of the European Parliament and of the Council of 15 May 2014 on the Protection of the Euro and Other Currencies against Counterfeiting by Criminal Law, and Replacing Council Framework Decision 2000/383/JHA,” Pub. L. No. 32014L0062, 151 151 (2014), 1-8, http://data.europa.eu/eli/dir/2014/62/oj/eng.

25 "Directive (EU) 2019/713 of the European Parliament and of the Council of 17 April 2019 on Combating Fraud and Counterfeiting of Non-Cash Means of Payment and Replacing Council Framework Decision 2001/413/JHA,” Pub. L. No. 32019L0713, 123123 (2019), 18-29, http://data.europa.eu/eli/dir/2019/713/oj/eng. 
procedures, enables the holder or user to transfer money or monetary value, including through digital means of exchange (Article 2).

Combat against money laundering is also given a specific importance among the measures against financial crimes in the EU. The Directive (EU) 2018/1673 on combating money laundering by criminal law ${ }^{26}$ defines criminal offences and sanctions in the area of money laundering with a view to combatting money laundering by means of criminal law and enabling more efficient and swifter cross-border cooperation between competent authorities (para. 1 of Recitals). Pursuant to the Directive, the sanction must be effective, proportionate and dissuasive, and the Member States must impose a maximum term of imprisonment of at least 4 years and, where necessary, apply additional sanctions or measures (Article 5).

Effective fight against financial crimes requires to authorise law enforcement authorities to freeze proceeds of crime. The Directive 2014/42/EU on the freezing and confiscation of instrumentalities and proceeds of crime in the $\mathrm{EU}^{27}$ establishes the minimum rules on the freezing of property with a view to possible subsequent confiscation and on the confiscation of property in criminal matters (Article 1). Moreover, the Regulation (EU) 2018/1805 on the mutual recognition of freezing orders and confiscation orders $^{28}$, which started to be applied on 19 December 2020, aims to facilitate the cross-border recovery of criminal assets and to lead to more efficient freezing and confiscation of crime proceeds in the EU (para. 12 of Recitals). The Regulation provides standard certificates and procedures to allow for quicker and more efficient freezing and confiscation actions (Article 6). It provides a deadline of 45 days for the recognition of a confiscation order (Article 20). In urgent cases, the executing authority shall decide on the recognition of the freezing order no later than 48 hours after it has been received by the executing authority; and no later than 48 hours after such a decision has been taken, the executing authority shall take the concrete measures necessary to execute the order (Article 9).

26 "Official Journal of the European Union, L 284, 12 November 2018," 22-30, accessed January 10, 2021, https://eur-lex.europa.eu/legal-content/EN/TXT/?uri=OJ\%3AL\%3 A2018\%3A284\%3ATOC.

27 "Official Journal of the European Union, L 127, 29 April 2014," 39-50, accessed January 10, 2021, https://eur-lex.europa.eu/legal-content/EN/TXT/?uri=OJ\%3AL\%3 A2014\%3A127\%3ATOC.

28 "Official Journal of the European Union, L 303, 28 November 2018," 1-38, accessed January 10, 2021, https://eur-lex.europa.eu/legal-content/EN/TXT/?uri=OJ\%3AL\%3 A2018\%3A303\%3ATOC. 
Ankara Üni. Hukuk Fak. Dergisi, 70 (1) 2021: 145-170 Police and Judicial Cooperation in Criminal...

\section{Fight against Cybercrime}

Cybercrime, in a broader sense, means any illegal behaviour committed by means of, or in relation to, a computer system or network, including such crimes as illegal possession and offering or distributing information by means of a computer system or network. ${ }^{29}$ Cybercrime consists of criminal acts that are committed online by using electronic communications networks and information systems, including crimes specific to the Internet, online fraud and forgery, and illegal online content, including child sexual abuse material and incitement to terrorist acts. ${ }^{30}$

Cybercrime is another area of focus for police and judicial cooperation in the EU. Since 2011, several legislative acts have been adopted by the EU authorities, including, the Directive on combating the sexual exploitation of children online and child pornography ${ }^{31}$, the Directive on attacks against information systems ${ }^{32}$, and the Directive on non-cash means of payment ${ }^{33}$. Among such legislation, the Directive 2013/40/EU on attacks against information systems (known as the "Cybercrime Directive") constitutes the main piece of legislation in that area.

The Cybercrime Directive establishes minimum rules concerning the definition of criminal offences and sanctions in the area of attacks against information systems, and aims to facilitate the prevention of such offences and to improve cooperation between judicial and other competent authorities (Article 1). Among other crimes, it covers illegal access to information systems, illegal system interference, illegal data interference and illegal interception (Articles 3 to 7). Pursuant to the Directive, Member States must take the necessary measures to ensure that the cybercrimes are punishable by

29 "10th UN Congress on the Prevention of Crime and the Treatment of Offenders," 5, accessed January 10, 2021, https://www.un.org/press/en/2000/20000410.soccp216.doc.html.

30 See "Cybercrime," Text, Migration and Home Affairs - European Commission, (December 6, 2016), https://ec.europa.eu/home-affairs/what-we-do/policies/cybercrime_en.

31 "Directive 2011/93/EU of the European Parliament and of the Council of 13 December 2011 on Combating the Sexual Abuse and Sexual Exploitation of Children and Child Pornography, and Replacing Council Framework Decision 2004/68/JHA," Pub. L. No. 32011L0093, 335335 (2011), http://data.europa.eu/eli/dir/2011/93/oj/eng.

32 "Directive 2013/40/EU of the European Parliament and of the Council of 12 August 2013 on Attacks against Information Systems and Replacing Council Framework Decision 2005/222/JHA,” accessed January 10, 2021, https://eur-lex.europa.eu/eli/dir/2013/40/oj.

33 "Directive (EU) 2019/713 of the European Parliament and of the Council of 17 April 2019 on Combating Fraud and Counterfeiting of Non-Cash Means of Payment and Replacing Council Framework Decision 2001/413/JHA,” Pub. L. No. 32019L0713, 123123 (2019), http://data.europa.eu/eli/dir/2019/713/oj/eng. 
effective, proportionate and dissuasive criminal penalties, including imprisonment and fines (Article 8).

To support the police cooperation on cybercrime in the EU, a specific body, called the European Cybercrime Centre, has been formed within Europol in 2013, to act as the focal point in the fight against cybercrime in the Union. $^{34}$

\section{MAIN LEGAL INSTRUMENTS FOR COOPERATION}

\section{A. Extradition: Traditional Method}

Extradition basically refers to a cooperative law enforcement process between two jurisdictions whereby one jurisdiction delivers a person accused or convicted of committing a crime in another jurisdiction, over to their law enforcement. ${ }^{35}$ Besides the legal aspects of the process, extradition also involves the physical transfer of custody of the person being extradited to the legal authority of the requesting jurisdiction. ${ }^{36}$

Extradition in the EU is mainly governed by the European Convention on Extradition of 1957. ${ }^{37}$ It provides for the extradition of persons wanted for criminal proceedings or for the carrying out of a sentence. The Convention does not apply to political (Article 3.1) or military offences (Article 4). It also provided that any contracting country could refuse to extradite its own nationals to a foreign country (Article 6).

As regards fiscal offences, extradition may be granted for offences in connection with taxes, duties, customs and exchange only if the contracting countries have so decided in respect of any such offence or category of offences (Article 5).

Extradition may also be refused if the offence for which extradition is requested is punishable by death under the law of the requesting country. If in

34 See "European Cybercrime Centre - EC3," Europol, accessed January 10, 2021, https://www.europol.europa.eu/about-europol/european-cybercrime-centre-ec3.

35 Amna Hassan, "Extradition," April 9, 2020, 2, https://www.researchgate.net/publication/340538712_Extradition.

36 David A. Sadoff, Bringing International Fugitives to Justice: Extradition and Its Alternatives (Cambridge: Cambridge University Press, 2016), 43, doi:10.1017/9781316422922. For an analysis on the difference between extradition and surrender, see Libor Klimek, "Surrender vs. Extradition: A Comparison Focused on Innovations of European Arrest Warrant," International and Comparative Law Review 11 (June 1, 2011): 145-56.

37 ETS No. 024 dated 13 December 1957. Available at "European Convention on Extradition," accessed January 10, 2021, https://www.coe.int/en/web/conventions/full-list. 
respect of such offence the death-penalty is not provided for by the law of the requested country or is not normally carried out, extradition may be refused unless the requesting country gives such assurance as the requested country considers sufficient that the death-penalty will not be carried out (Article 11).

The European Convention on Extradition of 1957 was later complemented by two new conventions. In 1995, the Convention on simplified extradition procedure between the Member States of the European Union $^{38}$ was signed. The 1995 Convention provided the application of this simplified procedure in the extradition of the requested person if the requested person consents to his/her surrender (Article 2).

In 1996, the Convention on extradition between member states of European Union ${ }^{39}$ provided, contrary to the 1995 Convention, the ordinary extradition proceeding without the consent of the requested person for the surrender. ${ }^{40}$

The 1996 Convention aims to facilitate extradition between the Member States by specifying the circumstances in which the extradition procedure is applicable. They mainly include the offences which are punishable under the law of the requesting Member State by deprivation of liberty or a detention order for a maximum period of at least 12 months and under the law of the requested Member State by deprivation of liberty or a detention order for a maximum period of at least six months (Article 2). The Convention also specifically mentions extradition in the case of conspiracy or an association to commit offences, provided the conspiracy or the association is to commit a crime related to suppression of terrorism, drug trafficking or certain forms of crime against individual freedoms or creating a collective danger (Article 3 ).

Differently from the 1957 Convention, the 1996 Convention provided that extradition may not, in principle, be refused on the ground that the person claimed is a national of the requested Member State (Article 7).

Although the 1996 Convention has been replaced since 1 January 2004 by the Council Framework Decision on the European arrest warrant, it can still be applied in cases where the European arrest warrant cannot be applied.

38 "Official Journal of the European Communities, C 78, 30 March 1995," accessed January 10, 2021, https://eur-lex.europa.eu/legal-content/EN/TXT/?uri=OJ:C:1995:078:TOC.

39 "Official Journal of the European Communities, C 313, 23 October 1996."

40 Mar Jimeno-Bulnes, "European Judicial Cooperation in Criminal Matters," European Law Journal 9, no. 5 (2003): 622. 


\section{B. The European Arrest Warrant: Paradigm Shift}

The European arrest warrant is a cross-border judicial surrender procedure for prosecuting or executing a custodial sentence or detention order issued by a judicial authority of one Member State in the entire EU.

The European arrest warrant is based on the principle of mutual recognition of judicial decisions. Its legal basis is the Council Framework Decision of 13 June 2002 on the European arrest warrant and the surrender procedures between Member States ${ }^{41}$. It differs from traditional extradition in several aspects, including (i) no political involvement as decisions are made by judicial authorities alone (Article 1.1), (ii) double criminality check (i.e. verification on whether the act is a criminal offence in both countries) no longer being required for 32 categories of offences (Article 2.2), (iii) prohibition for Member States to refuse surrendering their own nationals, and limited grounds for refusal to surrender (Articles 3 and 4), and (iv) strict time limits (Article 17).

In applying a European arrest warrant, authorities must also respect the procedural rights of suspects or accused persons, such as the right to information, to have a lawyer, and an interpreter, and to legal aid (Recitals 12 and 13, Article 11). ${ }^{42}$

The European arrest warrant simplified and replaced the lengthy extradition procedures that used to exist prior to the Council Framework Decision of 2002. According to Alison Saunders, the former director of public prosecutions in the UK, the European arrest warrant is "three times faster and four times less expensive than the alternatives". ${ }^{43}$

The European arrest warrant represents a paradigm shift from lack of trust to mutual recognition between the Member States. On a theoretical level,

41 "2002/584/JHA: Council Framework Decision of 13 June 2002 on the European Arrest Warrant and the Surrender Procedures between Member States - Statements Made by Certain Member States on the Adoption of the Framework Decision," Pub. L. No. 32002F0584, 190 OJ L (2002), http://data.europa.eu/eli/dec_framw/2002/584/oj/eng.

42 For an analysis of the European arrest warrant from the perspective of the protection of fundamental rights, see İlke Göçmen, "The Contribution of the Court of Justice of the European Union to Judicial Cooperation in Criminal Matters with a Specific Focus on the Protection of Fundamental Rights," Ankara Avrupa Çalışmaları Dergisi 12, no. 1 (May 1, 2013): 129-70.

43 See Amanda Kramer and Rachael Dickson, "The UK Is Leaving the European Arrest Warrant - and Extraditing Criminals Could Be More Difficult as a Result," The Conversation, accessed January 10, 2021, http://theconversation.com/the-uk-is-leaving-theeuropean-arrest-warrant-and-extraditing-criminals-could-be-more-difficult-as-a-result133579. 
the introduction of a European arrest warrant instead of traditional extradition reflects a genuine paradigm shift in legal cooperation between Member States. Traditionally, under the extradition treaties, such cooperation was based on the rule that one Member State does not execute or enforce decisions of another Member State, whereas the European arrest warrant is based on the principle that Member States automatically recognise each other's judicial decisions ordering the arrest of a person. ${ }^{44}$

Despite such improvements brought by the European arrest warrant procedure as compared to its precedent traditional extradition, its implementation by Member States is still not at the desired level. Although the European Arrest Warrant was meant to enable near-automatic extradition within the EU, some recent European Court of Justice decisions indicate a continuing lack of trust between the Member States. ${ }^{45}$

\section{Mutual Assistance in Criminal Matters}

Mutual assistance is a legal instrument for cooperation between the Member States for the purpose of collecting and exchanging information on criminal matters.

The main legal instrument governing the mutual assistance in criminal matters in the EU is the "Convention established by the Council in accordance with Article 34 of the Treaty on European Union, on Mutual Assistance in Criminal Matters between the Member States of the European Union". ${ }^{46}$ It supplements the 1959 Council of Europe Convention on Mutual Assistance in Criminal Matters ${ }^{47}$ and its 1978 Additional Protocol ${ }^{48}$.

44 Jan Wouters and Frederik Naert, "Of Arrest Warrants, Terrorist Offences and Extradition Deals: An Appraisal of the EU's Main Criminal Law Measures against Terrorism after 11 September," Common Market Law Review 41, no. 4 (August 1, 2004): 11, https://kluwerlawonline.com/journalarticle/Common+Market+Law+Review/41.4/COLA20 04034.

45 For a criticism of the application of the European Arrest Warrant by the Member States, see Camino Mortera-Martinez, "Extradition Cases Signal Alarming Trust Issues in the EU," Centre for European Reform, April 4, 2019, https://www.cer.eu/in-the-press/extraditioncases-signal-alarming-trust-issues-eu.

46 "Official Journal of the European Communities, C 197, 12 July 2000," accessed January 10, 2021, https://eur-lex.europa.eu/legalcontent/en/ALL/?uri=OJ\%3AC\%3A2000\%3A197\%3ATOC.

47 "Details of Treaty No.030 European Convention on Mutual Assistance in Criminal Matters," Treaty Office, accessed January 10, 2021, https://www.coe.int/en/web/conventions/full-list.

48 "Additional Protocol to the European Convention on Mutual Assistance in Criminal Matters," March 17, 1978, https://rm.coe.int/1680077975. 
The Convention aims to improve judicial cooperation in criminal matters between the Member States, without prejudice to the rules protecting individual freedom, and to ensure mutual assistance between the Member States in a fast and efficient manner compatible with the basic principles of their national law, and in compliance with the principles of the protection of human rights and fundamental freedoms.

Pursuant to the Convention, a request for mutual assistance must be made in writing, transmitted and carried out directly by the national judicial authorities (Article 6.1). In emergencies, requests may be made via Interpol or any other body competent under rules introduced under the Treaty on European Union (Article 6.4).

The EU country requested to provide mutual assistance (requested country) must comply with the formalities and procedures specified by the EU country which made the request (requesting country) and must carry out the request as soon as possible, taking as full account as possible of the deadlines indicated (Article 4.2).

Furthermore, Member States may also spontaneously share information regarding criminal offences and administrative infringements whose punishment or handling is the responsibility of the receiving authority (Article $6.1)$.

The Convention is supplemented by an implementation protocol dated 16 October 2001, which envisages certain additional measures specific to organised and financial crimes. ${ }^{49}$

Mutual legal assistance mechanisms have been progressively replaced by mutual recognition of judicial decisions, which is analysed in the following sub-section.

\section{Mutual Recognition of Judicial Decisions}

Mutual recognition refers to a procedural instrument whereby a judicial decision adopted by the competent authorities of a Member State can be automatically recognised and enforced in other Member States. Automaticity in this context means a national decision being enforced beyond the territory of the issuing Member State by authorities in other EU Member States without many questions being asked and with the requested authority having at its

49 "Details of Treaty No.182 Second Additional Protocol to the European Convention on Mutual Assistance in Criminal Matters," Treaty Office, accessed January 10, 2021, https://www.coe.int/en/web/conventions/full-list. 
disposal extremely limited, if any at all, grounds to refuse the request for cooperation. ${ }^{50}$

Although it is the acceptance of the high level of integration among EU Member States which has justified automaticity in inter-state cooperation, mutual recognition is attractive to Member States resisting further harmonisation or unification in European criminal law, since mutual recognition is thought to enhance inter-state cooperation in criminal matters without Member States having to change their national laws to comply with EU harmonisation requirements. ${ }^{51}$

Since the entry into force of the Lisbon Treaty in 2009 the principle of mutual recognition is codified in the Treaty on the Functioning of the European Union, in particular its Article 82 (2) which explicitly serves to facilitate mutual recognition. This emphasis on the principle of mutual recognition in the Treaty on the Functioning of the European Union shows that this concept has become paramount for closer cooperation in criminal matters in the EU. ${ }^{52}$

One of the most significant implications of the mutual recognition is the European Arrest Warrant, which, as explained in sub-section B above, is based on the principle that Member States automatically recognise each other's judicial decisions ordering the arrest of a person.

The principle of mutual recognition is also closely linked with the ne bis in idem principle, which requires that a person who has been judged in a Member State for a specific fact or facts cannot be judged again for the same facts, either in the same or in another Member State. ${ }^{53}$

The principle of mutual recognition raises some concerns with respect to its compliance with the protection of fundamental rights. Such concerns have been analysed in some of the European Court of Justice (ECJ) cases, which demonstrated a change in the direction of the court's precedents in time. The

50 Valsamis Mitsilegas, "The Symbiotic Relationship between Mutual Trust and Fundamental Rights in Europe's Area of Criminal Justice," New Journal of European Criminal Law 6, no. 4 (December 1, 2015): 465.

51 Valsamis Mitsilegas, "The Constitutional Implications of Mutual Recognition in Criminal Matters in the EU," Common Market Law Review 43 (2006): 1277.

52 Frank Zimmermann, Sanja Glaser, and Andreas Motz, "Mutual Recognition and Its Implications for the Gathering of Evidence in Criminal Proceedings: A Critical Analysis of the Initiative for a European Investigation Order," European Criminal Law Review 1, no. 1 (June 1, 2011): 59.

53 Jimeno-Bulnes, "European Judicial Cooperation in Criminal Matters," 123. 
first case in this context was the case of $R a d u^{54}$, in which the Court rendered that the mutual recognition could not be refused on fundamental rights grounds, since the mutual recognition aims the establishment of a new simplified and more effective system for the surrender of persons convicted or suspected of having infringed criminal law, to facilitate and accelerate judicial cooperation with a view to contributing to the objective set for the EU to become an area of freedom, security and justice by basing itself on the high degree of confidence which should exist between the Member States. ${ }^{55}$ Similarly, in the Melloni case, the ECJ reiterated the effectiveness considerations. ${ }^{56}$

However, the case-law of the ECJ started to change direction with the Lanigan $^{57}$ decision in 2015, in which the Court made strong reference to the importance of respect for human rights, and emphasized the duty of both the issuing and the executing states to observe fundamental rights obligations. ${ }^{58}$ The Court reiterated such position in the Aranyosi and Căldăraru ${ }^{59}$ decision in 2016 by ruling that the execution of a European arrest warrant must be postponed if there is a real risk of inhuman or degrading treatment because of detention conditions in the requesting Member State. ${ }^{60}$ By such decision, the protection of human rights was clearly favoured over the efficient operation

54 "Judgment of the Court (Grand Chamber) of 29 January 2013. Proceedings Relating to the Execution of European Arrest Warrants Issued Agains Ciprian Vasile Radu.," accessed January $\quad 10, \quad 2021, \quad$ https://eur-lex.europa.eu/legalcontent/EN/TXT/?uri=CELEX\%3A62011CJ0396.

55 Ibid. para. 34.

56 "Judgment of the Court (Grand Chamber), 26 February 2013. Stefano Melloni v Ministerio Fiscal.," accessed January 10, 2021, https://eur-lex.europa.eu/legalcontent/EN/TXT/?uri=CELEX\%3A62011CJ0399.

57 "Judgment of the Court (Grand Chamber) of 16 July 2015 Minister for Justice and Equality v Francis Lanigan," accessed January 10, 2021, http://curia.europa.eu/juris/liste.jsf?num=C$237 / 15$.

58 Auke Willems, "The Court of Justice of the European Union's Mutual Trust Journey in EU Criminal Law: From a Presumption to (Room for) Rebuttal," German Law Journal 20, no. 4 (May 2019): 488.

59 "Judgment of the Court (Grand Chamber) of 5 April 2016. Pál Aranyosi and Robert Căldăraru v Generalstaatsanwaltschaft Bremen.," accessed January 10, 2021, https://eurlex.europa.eu/legal-content/EN/TXT/?uri=ecli:ECLI:EU:C:2016:198.

60 For an analysis of the difference between the approaches of the European Court of Justice and the European Court of Human Rights with respect to the balance between the mutual trust principle and the protection of fundamental rights, see İlke Göçmen, "Karş1lıklı Güven İlkesi ile Temel Hakların Korunması Arasındaki Makul Denge Arayışı: Avrupa Tutuklama Müzekkeresi Örneği," Marmara Üniversitesi Avrupa Topluluğu Enstitüsü Avrupa Araştırmaları Dergisi 27, no. 1 (June 30, 2019): 14. 
of mutual recognition in the jurisprudence on criminal justice. ${ }^{61}$ Subsequent decisions of the ECJ confirmed that there are limits of the mutual recognition stemming from the human rights, such as the Bob-Dogi ${ }^{62}$ and Dworzecki ${ }^{63}$ decisions.

\section{CONCLUDING REMARKS}

Cooperation in criminal matters in the EU is probably one of the most delicate issues in the area of harmonisation, as it deals with two very sensitive matters, namely, the sovereignty of Member States and the protection of human rights.

Until the Treaty of Lisbon, criminal law was considered as an area closely linked to and almost reserved for the sovereignty by the Member States rather than an EU matter. Whilst structures and organs of the EU were utilised to criminal justice ends, these were very deliberately characterised as serving the member states ${ }^{64}$ In the post-Cold War era, the nature of cross-border security threats has changed ${ }^{65}$, which lead to globalisation of criminal law. One of the most significant innovations of the Treaty of Lisbon was the conferral to the EU of certain competences in criminal matters, according to which the national legislator, in some cases, is under the obligation to adopt criminal provisions implementing choices of criminalization decided at the supranational level. ${ }^{66}$ The Treaty of Lisbon set out the objective of harmonising the EU criminal law within the supranational framework of "Judicial Cooperation in Criminal Matters" (Art. 82 et seq. of TFEU), which

61 Willems, "The Court of Justice of the European Union's Mutual Trust Journey in EU Criminal Law," 489.

62 "Judgment of the Court (Second Chamber) of 1 June 2016 Niculaie Aurel Bob-Dogi," accessed January 10, 2021, http://curia.europa.eu/juris/liste.jsf?language $=$ en\&num $=\mathrm{C}$ $241 / 15$.

63 "Judgment of the Court (Fourth Chamber) of 24 May 2016 Openbaar Ministerie v Paweł Dworzecki,” accessed January 10, 2021, http://curia.europa.eu/juris/liste.jsf?num=C$108 / 16$.

64 Marianne L. Wade, "True EU Citizenship as a Precursor to Genuine Criminal Justice in Europe: An Analysis of EU Citizenship as It Relates to a Sustainable Area of Freedom, Security and Justice," Criminal Law Forum 31, no. 3 (September 1, 2020): 301.

65 Valsamis Mitsilegas, "The European Union and the Globalisation of Criminal Law," Cambridge Yearbook of European Legal Studies 12 (2010): 337, https://www.cambridge.org/core/journals/cambridge-yearbook-of-european-legalstudies/article/abs/european-union-and-the-globalisation-of-criminallaw/C2CEBF0741E801D3375C5CD04E76FF7F.

66 Valeria Scalia, "Protection of Fundamental Rights and Criminal Law," The European Criminal Law Association's Forum, 2015, 100, https:/eucrim.eu/articles/protectionfundamental-rights-and-criminal-law/. 
is part of the "Area of Freedom, Security and Justice" (Art. 67 et seq. of TFEU).

However, the harmonisation of criminal law represents a number of peculiarities. Criminal justice purposes in the EU are deliberately based upon mutual recognition rather than more traditional EU approaches, such as full harmonisation. ${ }^{67}$ As a matter of fact, Article 83 of the TFEU rules out full harmonisation in criminal law, since it only establishes the "minimum rules" concerning the definition of criminal offences and sanctions, and only in the areas of particularly serious crimes with a cross-border dimension.

The above-stated delicate aspects also constitute the limits of the full harmonisation in criminal law. ${ }^{68}$ The EU criminal law have grown side by side with the strengthening of human rights. Therefore, the police and judicial cooperation in the EU is based on a delicate balance between the security concerns, on one hand, and the protection of fundamental rights. There is indeed a paradox between the criminal law and the fundamental rights. The criminal law is both a protection and a threat for fundamental rights and freedoms, which certain scholars express by describing the criminal law as both a "shield" of and a "sword" against human rights. ${ }^{69}$

Despite such delicate aspects, the police and judicial cooperation in criminal law has been one of the fastest-growing areas of the EU Law over the past few decades, and is expected to increase in the future by expanding the coverage of and diversifying the instruments used by the EU law enforcement authorities towards a more integrated EU criminal law system. Critical to achieve such improvements in an efficient but at the same time in a sustainable manner would be a balanced approach between the shield and sword functions of the criminal law as stated above.

67 Wade, "True EU Citizenship as a Precursor to Genuine Criminal Justice in Europe," 301.

68 Werner Schroeder, "Limits to European Harmonisation of Criminal Law," Eucrim - The European Criminal Law Associations' Forum, 2020, 148, https://eucrim.eu/articles/limitseuropean-harmonisation-criminal-law/.

69 See Françoise Tulkens, "The Paradoxical Relationship between Criminal Law and Human Rights," Journal of International Criminal Justice 9, no. 3 (July 1, 2011): 578. 
Ankara Üni. Hukuk Fak. Dergisi, 70 (1) 2021: 145-170 Police and Judicial Cooperation in Criminal...

\section{BIBLIOGRAPHY}

"10th UN Congress on the Prevention of Crime and the Treatment of Offenders." $\begin{array}{lll}\text { Accessed } & \text { January } & 2021 .\end{array}$ https://www.un.org/press/en/2000/20000410.soccp216.doc.html.

“211 Terrorist Attacks Carried out in the Member States in 2015.” Europol. Accessed January 10, 2021. https://www.europol.europa.eu/ newsroom/news/211 terrorist-attacks-carried-out-in-eu-member-states-in-2015-new-europol-reportreveals.

2002/584/JHA: Council Framework Decision of 13 June 2002 on the European arrest warrant and the surrender procedures between Member States - Statements made by certain Member States on the adoption of the Framework Decision, Pub. L. $\begin{array}{lllll}\text { No. } & 32002 \mathrm{~F} 0584, & 190 & \text { OJ } & \text { L }\end{array}$ http://data.europa.eu/eli/dec_framw/2002/584/oj/eng.

"Additional Protocol to the European Convention on Mutual Assistance in Criminal Matters," March 17, 1978. https://rm.coe.int/1680077975.

"Council Act of 19 June 1997 Drawing up, on the Basis of Article K.3 of the Treaty on European Union and Article 41 (3) of the Europol Convention, the Protocol on the Privileges and Immunities of Europol, the Members of Its Organs, the Deputy Directors and Employees of Europol.” Accessed January 10, 2021. https://eur-lex.europa.eu/legalcontent/EN/TXT/?uri=CELEX\%3A31997F0719\%2801\%29\&qid=1610297224 330 .

Council Act of 26 July 1995 drawing up the Convention on the protection of the European Communities' financial interests. Accessed January 10, 2021. https://eur-lex.europa.eu/legalcontent/EN/TXT/?uri=CELEX\%3A31995F1127\%2803\%29.

"Cybercrime." Text. Migration and Home Affairs - European Commission, December 6, 2016. https://ec.europa.eu/home-affairs/what-we-do/policies/cybercrime_en.

"Details of Treaty No.030 European Convention on Mutual Assistance in Criminal Matters." Treaty Office. Accessed January 10, 2021. https://www.coe.int/en/web/conventions/full-list.

"Details of Treaty No.182 Second Additional Protocol to the European Convention on Mutual Assistance in Criminal Matters." Treaty Office. Accessed January 10, 2021. https://www.coe.int/en/web/conventions/full-list.

Directive 2011/93/EU of the European Parliament and of the Council of 13 December 2011 on combating the sexual abuse and sexual exploitation of children and child pornography, and replacing Council Framework Decision 2004/68/JHA, Pub. L. No. 32011L0093, 335335 (2011). http://data.europa.eu/eli/dir/2011/93/oj/eng. 
Directive 2013/40/EU of the European Parliament and of the Council of 12 August 2013 on attacks against information systems and replacing Council Framework Decision 2005/222/JHA. Accessed January 10, 2021. https://eurlex.europa.eu/eli/dir/2013/40/oj.

Directive 2014/57/EU of the European Parliament and of the Council of 16 April 2014 on criminal sanctions for market abuse (market abuse directive), Pub. L. No. 32014L0057, 173173 (2014). http://data.europa.eu/eli/dir/2014/57/oj/eng.

Directive 2014/62/EU of the European Parliament and of the Council of 15 May 2014 on the protection of the euro and other currencies against counterfeiting by criminal law, and replacing Council Framework Decision 2000/383/JHA, Pub. $\begin{array}{lllll}\text { L. } & \text { No. } & \text { 32014L0062, } & 151 & 151\end{array}$ http://data.europa.eu/eli/dir/2014/62/oj/eng.

Directive (EU) 2016/681 of the European Parliament and of the Council of 27 April 2016 on the use of passenger name record (PNR) data for the prevention, detection, investigation and prosecution of terrorist offences and serious crime. Accessed January 10, 2021. https://eur-lex.europa.eu/eli/dir/2016/681/oj.

Directive (EU) 2017/541 of the European Parliament and of the Council of 15 March 2017 on combating terrorism and replacing Council Framework Decision 2002/475/JHA and amending Council Decision 2005/671/JHA, Pub. L. No. 32017L0541, 088088 (2017). http://data.europa.eu/eli/dir/2017/541/oj/eng.

Directive (EU) 2017/2103 of the European Parliament and of the Council of 15 November 2017 amending Council Framework Decision 2004/757/JHA in order to include new psychoactive substances in the definition of 'drug' and repealing Council Decision 2005/387/JHA, Pub. L. No. 32017L2103, 305305 (2017). http://data.europa.eu/eli/dir/2017/2103/oj/eng.

Directive (EU) 2019/713 of the European Parliament and of the Council of 17 April 2019 on combating fraud and counterfeiting of non-cash means of payment and replacing Council Framework Decision 2001/413/JHA, Pub. L. No. 32019L0713, 123123 (2019). http://data.europa.eu/eli/dir/2019/713/oj/eng.

Directive (EU) 2019/713 of the European Parliament and of the Council of 17 April 2019 on combating fraud and counterfeiting of non-cash means of payment and replacing Council Framework Decision 2001/413/JHA, Pub. L. No. 32019L0713, 123123 (2019). http://data.europa.eu/eli/dir/2019/713/oj/eng.

"EMCDDA | About." Accessed January 10, 2021. https://www.emcdda.europa.eu/about.

"EU Agenda and Action Plan on Drugs 2021-2025." European Economic and Social Committee, September 19, 2020. https://www.eesc.europa.eu/en/ourwork/opinions-information-reports/opinions/eu-agenda-and-action-plan-drugs2021-2025. 
Ankara Üni. Hukuk Fak. Dergisi, 70 (1) 2021: 145-170 Police and Judicial Cooperation in Criminal...

"EU Terrorism Situation and Trend Report 2020.” Europol. Accessed January 10, 2021.

https://www.europol.europa.eu/sites/default/files/documents/european_union_t errorism_situation_and_trend_report_te-sat_2020_0.pdf.

Euronews. "EU Countries Lose $€ 15$ Billion in Tax Revenues to Counterfeiting, Says New Report." Accessed January 10, 2021. https:/www.euronews.com/2020/06/10/eu-countries-lose-15-billion-in-taxrevenues-to-counterfeiting-says-new-report.

European Convention on Extradition. Accessed January 10, 2021. https://www.coe.int/en/web/conventions/full-list.

"European Council Conclusions, 10-11 December 2020," n.d. https://www.consilium.europa.eu/media/47296/1011-12-20-euco-conclusionsen.pdf.

"European Cybercrime Centre - EC3.” Europol. Accessed January 10, 2021. https://www.europol.europa.eu/about-europol/european-cybercrime-centre-ec3.

European Monitoring Centre for Drugs and Drug Addiction. and European Police Office. EU Drug Markets: Impact of COVID 19. LU: Publications Office, 2020. https://data.europa.eu/doi/10.2810/19284.

European Monitoring Centre for Drugs and Drug Addiction. and European Union Agency for Law Enforcement Cooperation. EU Drug Markets Report 2019. LU: Publications Office, 2019. https://data.europa.eu/doi/10.2810/561192.

Göçmen, İlke. "Karşılıklı Güven İlkesi ile Temel Hakların Korunması Arasındaki Makul Denge Arayışı: Avrupa Tutuklama Müzekkeresi Örneği." Marmara Üniversitesi Avrupa Topluluğu Enstitüsü Avrupa Araştırmaları Dergisi 27, no. 1 (June 30, 2019): 1-28.

Göçmen, İlke. "The Contribution of the Court of Justice of the European Union to Judicial Cooperation in Criminal Matters with a Specific Focus on the Protection of Fundamental Rights.” Ankara Avrupa Çalışmaları Dergisi 12, no. 1 (May 1, 2013): 129-70.

Hassan, Amna. "Extradition," April 2020. https://www.researchgate.net/publication/340538712_Extradition.

Jimeno-Bulnes, Mar. "European Judicial Cooperation in Criminal Matters." European Law Journal 9, no. 5 (2003): 614-30.

"Joint Statement by the EU Home Affairs Ministers on the Recent Terrorist Attacks in Europe." Accessed January 2021. https://www.consilium.europa.eu/en/press/press-releases/2020/11/13/jointstatement-by-the-eu-home-affairs-ministers-on-the-recent-terrorist-attacks-ineurope/. 
"Judgment of the Court (Fourth Chamber) of 24 May 2016 Openbaar Ministerie v Paweł Dworzecki." Accessed January 10, 2021. http://curia.europa.eu/juris/liste.jsf?num=C-108/16.

"Judgment of the Court (Grand Chamber), 26 February 2013. Stefano Melloni v Ministerio Fiscal.” Accessed January 10, 2021. https://eur-lex.europa.eu/legalcontent/EN/TXT/?uri=CELEX\%3A62011CJ0399.

"Judgment of the Court (Grand Chamber) of 5 April 2016. Pál Aranyosi and Robert Căldăraru v Generalstaatsanwaltschaft Bremen.” Accessed January 10, 2021. https://eur-lex.europa.eu/legalcontent/EN/TXT/?uri=ecli:ECLI:EU:C:2016:198.

"Judgment of the Court (Grand Chamber) of 16 July 2015 Minister for Justice and Equality v Francis Lanigan." Accessed January 10, 2021. http://curia.europa.eu/juris/liste.jsf?num=C-237/15.

"Judgment of the Court (Grand Chamber) of 29 January 2013. Proceedings Relating to the Execution of European Arrest Warrants Issued Agains Ciprian Vasile Radu." Accessed January 10, 2021. https://eur-lex.europa.eu/legalcontent/EN/TXT/?uri=CELEX\%3A62011CJ0396.

"Judgment of the Court (Second Chamber) of 1 June 2016 Niculaie Aurel Bob-Dogi." Accessed January 10, 2021. $\mathrm{http} / / /$ curia.europa.eu/juris/liste.jsf?language=en\&num=C-241/15.

Klimek, Libor. "Surrender vs. Extradition: A Comparison Focused on Innovations of European Arrest Warrant." International and Comparative Law Review 11 (June 1, 2011).

Kramer, Amanda, and Rachael Dickson. "The UK Is Leaving the European Arrest Warrant - and Extraditing Criminals Could Be More Difficult as a Result.” The Conversation. Accessed January 10, 2021. http://theconversation.com/the-uk-isleaving-the-european-arrest-warrant-and-extraditing-criminals-could-be-moredifficult-as-a-result-133579.

Mitsilegas, Valsamis. "The Constitutional Implications of Mutual Recognition in Criminal Matters in the EU." Common Market Law Review 43 (2006): 12771311.

. "The European Union and the Globalisation of Criminal Law." Cambridge Yearbook of European Legal Studies 12 (2010). https://www.cambridge.org/core/journals/cambridge-yearbook-of-europeanlegal-studies/article/abs/european-union-and-the-globalisation-of-criminallaw/C2CEBF0741E801D3375C5CD04E76FF7F.

. "The Symbiotic Relationship between Mutual Trust and Fundamental Rights in Europe's Area of Criminal Justice." New Journal of European Criminal Law 6, no. 4 (December 1, 2015): 457-80. 
Mortera-Martinez, Camino. "Extradition Cases Signal Alarming Trust Issues in the EU." Centre for European Reform, April 4, 2019. https://www.cer.eu/in-thepress/extradition-cases-signal-alarming-trust-issues-eu.

“Official Journal of the EuAropean Communities, C 78, 30 March 1995.” Accessed January $\quad 2021$ 10, https://eur-lex.europa.eu/legalcontent/EN/TXT/?uri=OJ:C:1995:078:TOC.

“Official Journal of the European Communities, C 151, 20 May 1997.” Accessed January $\quad 10,2021 . \quad$ https:/eur-lex.europa.eu/legalcontent/en/ALL/?uri=OJ\%3AC\%3A1997\%3A151\%3ATOC.

“Official Journal of the European Communities, C 197, 12 July 2000.” Accessed January $\quad 10, \quad 2021 . \quad$ https:/eur-lex.europa.eu/legalcontent/en/ALL/?uri=OJ\%3AC\%3A2000\%3A197\%3ATOC.

“Official Journal of the European Communities, C 313, 23 October 1996." Accessed January $\quad 10,2021 . \quad$ https://eur-lex.europa.eu/legalcontent/en/ALL/?uri=OJ\%3AC\%3A1996\%3A313\%3ATOC.

“Official Journal of the European Union, L 127, 29 April 2014.” Accessed January 10, 2021.2 https:/eur-lex.europa.eu/legalcontent/EN/TXT/?uri=OJ\%3AL\%3A2014\%3A127\%3ATOC.

“Official Journal of the European Union, L 173, 12 June 2014.” Accessed January 10, $2021 . \quad$ https:/eur-lex.europa.eu/legalcontent/EN/TXT/?uri=OJ\%3AL\%3A2014\%3A173\%3ATOC.

“Official Journal of the European Union, L 198, 28 July 2017.” Accessed January 10, 2021. https://eur-lex.europa.eu/legalcontent/EN/TXT/?uri=OJ\%3AL\%3A2017\%3A198\%3ATOC.

“Official Journal of the European Union, L 284, 12 November 2018.” Accessed January $\quad 10,2021 . \quad$ https://eur-lex.europa.eu/legalcontent/EN/TXT/?uri=OJ\%3AL\%3A2018\%3A284\%3ATOC.

"Official Journal of the European Union, L 303, 28 November 2018." Accessed January $\quad 10,2021 . \quad$ https:/eur-lex.europa.eu/legalcontent/EN/TXT/?uri=OJ\%3AL\%3A2018\%3A303\%3ATOC.

Regulation (EC) No 1920/2006 of the European Parliament and of the Council of 12 December 2006 on the European Monitoring Centre for Drugs and Drug Addiction (recast), Pub. L. No. 32006R1920, 376 OJ L (2006). http://data.europa.eu/eli/reg/2006/1920/oj/eng.

Sadoff, David A. Bringing International Fugitives to Justice: Extradition and Its Alternatives. Cambridge: Cambridge University Press, 2016. doi:10.1017/9781316422922. 
Scalia, Valeria. "Protection of Fundamental Rights and Criminal Law." The European Criminal Law Association's Forum, 2015. https://eucrim.eu/articles/protectionfundamental-rights-and-criminal-law/.

Schroeder, Werner. "Limits to European Harmonisation of Criminal Law." Eucrim The European Criminal Law Associations' Forum, 2020. https://eucrim.eu/articles/limits-european-harmonisation-criminal-law/.

Tulkens, Françoise. "The Paradoxical Relationship between Criminal Law and Human Rights." Journal of International Criminal Justice 9, no. 3 (July 1, 2011): 577-95.

Villani, Susanna. "Some Further Reflections on the Directive (EU) 2016/681 on PNR Data in the Light of the CJEU Opinion 1/15 of 26 July 2017." Revista de Derecho Político 1 (April 28, 2018): 899.

Wade, Marianne L. "True EU Citizenship as a Precursor to Genuine Criminal Justice in Europe: An Analysis of EU Citizenship as It Relates to a Sustainable Area of Freedom, Security and Justice." Criminal Law Forum 31, no. 3 (September 1, 2020): 291-344.

Willems, Auke. "The Court of Justice of the European Union's Mutual Trust Journey in EU Criminal Law: From a Presumption to (Room for) Rebuttal." German Law Journal 20, no. 4 (May 2019): 468-95.

Wouters, Jan, and Frederik Naert. "Of Arrest Warrants, Terrorist Offences and Extradition Deals: An Appraisal of the EU's Main Criminal Law Measures against Terrorism after 11 September." Common Market Law Review 41, no. 4 (August

https://kluwerlawonline.com/journalarticle/Common+Market+Law+Review/41 .4/COLA2004034.

Zimmermann, Frank, Sanja Glaser, and Andreas Motz. "Mutual Recognition and Its Implications for the Gathering of Evidence in Criminal Proceedings: A Critical Analysis of the Initiative for a European Investigation Order." European Criminal Law Review 1, no. 1 (June 1, 2011): 55-79. 